\title{
New outlook in BOD measurement and bioprocess management: the Enverdi® kit
}

\author{
Mathieu Muller ${ }^{1, *}$, Solenn Bellaton ${ }^{1}$, Alison Yoris ${ }^{1}$, Sabrina Guérin-Rechdaoui ${ }^{2}$, Laurent Clousier ${ }^{1,3}$, and Vincent \\ Rocher $^{2}$ \\ ${ }^{1}$ AMS Envolure, Cap Delta, 1682 rue de la Valsière, 34790 Grabels, France \\ ${ }^{2}$ SIAAP, Direction du Développement et de la Prospective, 82 avenue Kléber, 92700 Colombes, France \\ ${ }^{3}$ AMS France, 10 avenue Charles de Gaulle, 95740 Frépillon, France
}

\begin{abstract}
Knowing the quantity and biodegradability of wastewater organic matter (OM) is really essential for the optimization of modern biological treatment processes, particularly when considering the highly challenging context for sewage treatment plant operators. However, the current standard methods for wastewater characterisation, as for 5-days biochemical oxygen demand (BOD5) measurement, OM fractionation analysis and bacterial inhibitor detection, show very poor suitability for routine operational use. In this paper, the efficiency of the commercial Enverdi ${ }^{\circledR}$ method (fluorimetric respirometry) for such analytical applications is investigated, especially for the BOD5-equivalent measurement in municipal wastewater samples. The result of numerous experiments showed that the BOD5 values obtained from the alternative Enverdi ${ }^{\circledR}$ method and the main standard methods are statistically equivalent. The analytical performances of the Enverdi $\mathbb{R}$ method was found similar to the standard BOD5 method specifications and perfectly matched the French regulatory requirements in force. The regulatory acceptance of this method is presently under consideration. Such an outlook would be really valuable for end-users given the main advantages of this analytical solution which is time- and space-saving, user-friendly and financially competitive. In addition to BOD5 measurement, the fluorimetric respirometry displayed very promising abilities for the $\mathrm{OM}$ fractionation and the detection of bacterial inhibitors in wastewater.
\end{abstract}

\section{Introduction}

Organic matter (OM) is one of the major pollutants in wastewater including both biodegradable and nonbiodegradable fractions. Usually, the total organic matter in wastewater is described by the Chemical Oxygen Demand (COD) while the Biochemical Oxygen Demand (BOD) is used to appraise the biodegradable fraction of organic matter (BOM) [1]. In order to preserve the aquatic environments, the European authorities have established COD and BOD quality standards for controlling the effluent discharges in freshwater or in the sewer network [2]. Otherwise, the COD/BOD ratio is a well-known index to assess the organic pollution biodegradability in wastewater [1].

Besides the control of effluent conformity, the BOD measurement in wastewater is particularly crucial for sewage treatment plant (STP) operation given the wide use of biological processes in wastewater treatment. However, the analytical methods currently available for the BOD measurement drastically suffer from a lack of operational suitability. These methods are lengthy and tedious while the operation of modern STP requires a high responsiveness through fast and easy-to-use analytical tools [3-4]. In the last decades, the biological processes for wastewater treatment have substantially changed to match the stricter and stricter effluent quality standards decreed by the European authorities. Thus, the traditional activated sludge process was progressively replaced with advanced biological filters and membrane bioreactors $[1,5]$. Such compact and intensive biological processes are faster and more efficient than the classic aeration tanks for pollution removal but they are also more complex to manage, costly and energy intensive. Presently, the STP operation must lead to high quality effluents while minimizing the operating cost and the environmental footprint of the treatment (energy and reagent consumption, greenhouse gas emission) [5]. Consequently, the STP operation should be continuously adapted to the wastewater characteristics but, amazingly, the analytical methods for characterisation of wastewater did not evolve in the same extent than the effluent quality standards, the biological treatment processes and the operating constraints did.

Besides faster BOD measurement, the operation of modern STP needs mathematical modelling to adjust the treatment parameters according to the wastewater characteristics. However, such models require data from advanced OM fractionation analysis to fully describe the biological kinetics during wastewater treatment [1].

* Corresponding author: mathieu.muller@envolure.com

(C) The Authors, published by EDP Sciences. This is an open access article distributed under the terms of the Creative Commons Attribution License 4.0 (http://creativecommons.org/licenses/by/4.0/). 
Otherwise, the occurrence of bacterial inhibitors in wastewater which can affect the efficiency of biological treatment, especially nitrogen removal, should require a particular attention in highly industrialised area [6].

This article reviews the ability of the innovative Enverdi ${ }^{\circledR}$ technology, based on the fluorimetric detection of bacterial respiration, for quickly measuring the wastewater BOD. Additionally, an overview is given regarding further useful applications for bioprocess management like the biological fractionation of $\mathrm{OM}$ according to biodegradability criteria and the detection of bacterial inhibitors in wastewater.

\subsection{BOD measurement}

\subsubsection{Definition and history}

The BOD parameter is closely related to the effect of the organic pollution on the DO concentration in freshwater. When mineralizing BOM under aerobic conditions, heterotrophic bacteria consume the DO through the respiration mechanism. This natural process causes DO depletion but ensure the self-purification of water bodies. However, the release of high loads of BOM in freshwater can result in a harmful asphyxia of the aquatic ecosystems which decreases the biodiversity and leads to unusable and non-drinkable water resources [7].

The BOD is defined as the DO concentration, in $\mathrm{mg}$ $\mathrm{O}_{2} . \mathrm{L}^{-1}$, required by heterotrophic bacteria, in specified conditions, for BOM mineralization [8]. This index of water quality focussing on the biodegradable organic pollution was suggested in 1912, in UK, by the Royal Commission on Sewage Disposal [9]. Back then, the selected conditions for BOD determination were a 5 days incubation period at $18.3^{\circ} \mathrm{C}$. The origin of these conditions was so unclear that the time and temperature of incubation were sharply criticized in the following years [10]. Even through alternative conditions (2 or 7 days and 15 or $27^{\circ} \mathrm{C}$ ) were rapidly suggested, the 5 days period has persisted up to day while the temperature was standardized later at $20^{\circ} \mathrm{C}$. In these conditions, 5 days at $20^{\circ} \mathrm{C}$, the BOD is known as the BOD5 parameter.

\subsubsection{Standard analytical methods}

The main BOD measurement method for wastewater is described quite similarly in the European EN 1899-1, the international ISO 5815-1 and the American 5210-B standards. Basically, the water sample is diluted in an oxygen-saturated $\mathrm{pH}$ and salt buffer and seeded with bacteria in a 150 or $300 \mathrm{~mL}$ flask. The DO is measured at the initial time, before to hermetically close the flask, and after the incubation period in darkness. Initially the DO was measured by titrimetric analysis which was replaced later with electrochemical probes [3]. The EN and ISO standards are now considering the DO measurement using optical probes.

The "5 d / $20^{\circ} \mathrm{C}$ " incubation period is the most common condition used in the world. However, in some European Nordic and Baltic countries, a 7 days period at $20^{\circ} \mathrm{C}$ (BOD7), also described by the EN 1899-1
European standard, was adopted [4]. In India, the standard method IS 3025-44 opts for a " $3 \mathrm{~d} / 27^{\circ} \mathrm{C}$ " incubation period resulting in similar $\mathrm{BOD}$ values than the " $5 \mathrm{~d} / 20^{\circ} \mathrm{C}$ " standard method. Indeed, according to the well-known biochemical model which govern oxygen uptake by bacteria, the influence of the incubation time and temperature on the BOD value is illustrated in equation (1) [11]. At a specified temperature $T$, the $B O D(t, T)$ increases exponentially over the time $t$ up to the ultimate BOD value $(u B O D)$ which is an intrinsic property of the analysed sample. Usually, the $B O D u$, corresponding to the complete mineralization of the $\mathrm{BOM}$, is reached after 15 to 30 days at $20^{\circ} \mathrm{C}$ while the BOD5 value represents about 60 to $70 \%$ of the $u B O D$ [12].

$$
\begin{aligned}
& B O D(t, T)=u B O D \cdot\left[1-e^{-k(T) \cdot t}\right] \\
& k(T)=k\left(20^{\circ} \mathrm{C}\right) \cdot \theta^{\left(T-20^{\circ} \mathrm{C}\right)}
\end{aligned}
$$

On another hand, the reaction rate $k(T)$ is dependant of the temperature $T$ according to the equation (2), with the temperature coefficient $\theta$ showing a constant value in the range of $10-35^{\circ} \mathrm{C}[11,13]$. Whereas the reaction rate at $20^{\circ} \mathrm{C}, k\left(20^{\circ} \mathrm{C}\right)$, is ranging from 0.20 to $0.25 \mathrm{~d}^{-1}$, the $k(T)$ value increases when the temperature rises, up to a maximum around $35^{\circ} \mathrm{C}$ for mesophilic bacteria [11-13]. This means that the $\mathrm{BOM}$ mineralization and the resulting oxygen uptake are faster at $27^{\circ} \mathrm{C}$ than at $20^{\circ} \mathrm{C}$. That is why the BOD value obtained after a " $3 \mathrm{~d} / 27^{\circ} \mathrm{C}$ " incubation period is similar to the one obtained after a " 5 $\mathrm{d} / 20^{\circ} \mathrm{C}$ " incubation period. As shown in Fig. 1, data from the literature clearly highlights this point. Thus, a " $5 \mathrm{~d} / 20^{\circ} \mathrm{C}$ " BOD-equivalent value could be obtained after " $30 \mathrm{~d} / 5^{\circ} \mathrm{C}$ " or " $2 \mathrm{~d} / 30^{\circ} \mathrm{C}$ " incubation periods as well. Inversely, the DBO value obtained after 7 days at $20^{\circ} \mathrm{C}$ is higher than the one obtained at the same temperature after 5 days. According to the EN 1899-1 standard, the BOD7 value is about 1.1 to 1.2 the BOD5 value.

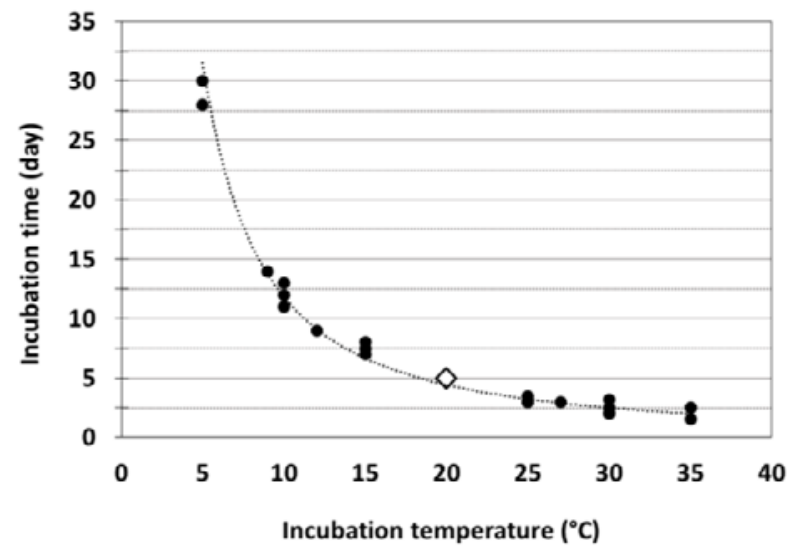

Fig. 1. Time-temperature binomials leading to a " $5 \mathrm{~d} / 20^{\circ} \mathrm{C}$ " BOD-equivalent value according to published data $[11,13-17]$.

Some national standards also described a manometric method for BOD measurement as the Norwegian NS 4758 and the American 5210-D standards. In this case, the hermetically closed flask shows a gaseous headspace 
and oxygen uptake is appraised by the air pressure decrease in presence of sodium hydroxide pellets [3]. These pellets insure the removal of gaseous carbon dioxide resulting from bacterial respiration. In addition to a continuous measurement of oxygen uptake, the main advantage of the manometric method over the traditional approach is the wider linear range of the response. This is due to the high quantity of oxygen available for bacteria (dissolved and gaseous) while, in the traditional approach, the available oxygen is limited to the dissolved phase which is around $9 \mathrm{mg} \mathrm{O} 2 \cdot \mathrm{L}^{-1}$ at $20^{\circ} \mathrm{C}$. Consequently, the manometric method requires lower sample dilution before analysis which could result in lower dilution errors. Moreover, according to the 5210-D standard, only 2 to 3 days are needed at $20^{\circ} \mathrm{C}$ to obtain a BOD value which is similar to the traditional BOD5. It can be assume that the higher quantity of available oxygen in the manometric method could increase the reaction rate of $\mathrm{BOM}$ mineralization by bacteria.

\subsubsection{Regulatory framework and shortcomings}

In the field of wastewater BOD measurement, the French regulation is very restrictive regarding the analytical methods. Only the EN 1899-1 standard method is allowed by the French decree dealing with wastewater treatment plant monitoring [18]. The corresponding European directive is quite less restrictive because any standard method is specified but the " $5 \mathrm{~d} / 20^{\circ} \mathrm{C}$ " incubation period is clearly pointed out [2]. However, as detailed previously, some Nordic and Baltic countries depart from this European obligation by using the BOD7. In a similar way, in Italy, the use of the 5210-D American standard with a " $5 \mathrm{~d} / 20^{\circ} \mathrm{C}$ " incubation period is allowed by the national regulations [19].

Whatever the method used, the 5 days incubation period required by the European directive and by most of the current standards, is fast enough for long time surveys of the STP effluent conformity. However, for an efficient management of biological treatment processes which requires highly responsive analytical tools, a 5 days incubation period is too long. Moreover, the current BOD measurement methods are really labour-intensive as well as time- and space-consuming [3-4].

\subsection{Organic matter fractionation}

Even though BOD is used worldwide since a long time as an index of the biodegradable organic pollution, this parameter is not sufficient enough to describe in details the BOM in wastewater. Today, a better knowledge of the wastewater $\mathrm{OM}$ is vital for the optimisation of modern biological treatment processes through the use of relevant mathematical models [1].

Up to now, the best way to describe the different fractions of wastewater $\mathrm{OM}$ is the fractionation model supplied by the Activated Sludge Model $n^{\circ} 1$ (ASM1) [20]. ASM1 splits the total OM (tCOD) into BOM $(b C O D)$ and inert (i.e. non-biodegradable) OM (iCOD). In addition, the $b C O D$ fraction is spitted into readily BOM $(S s)$ and slowly BOM $(S x)$. For instance, knowing the part of $S s$ and $S x$ fractions in wastewater is particularly useful for the regulation of organic substrate addition in biological post-denitrification processes.

The determination of the $b C O D$ can be appraised through the measurement of the $u B O D$. The $u B O D$ is usually measured by analyzing the raw wastewater using the manometric BOD method with an incubation period at $20^{\circ} \mathrm{C}$, in darkness, for at least 15 days. The analysis by this same method of the filtered wastewater in similar conditions can be used to assess the $S s$ fraction but, in this case, the filter pore size could greatly influence the result. Given than $t C O D$ is obtained by measuring the COD of the raw wastewater, $i C O D$ and $S x$ fractions are obtained by difference between, respectively, the $t C O D$ and $b C O D$ fractions and the $b C O D$ and $S s$ fractions. The other method commonly used for the determination of $S s, S x$ and $b C O D$ is measuring the Oxygen Uptake Rate of an activated sludge in presence of the wastewater sample, using an electrochemical respirometer (OUR test). In this case, $i C O D$ is also obtained by difference between the $t C O D$ and $b C O D$ fractions [21].

Although the manometric BOD is quite easy-to-use and inexpensive, the main shortcoming is the long time required for $u B O D$ measurement $(>15 \mathrm{~d})$. This makes the method not suitable enough for operational applications. Inversely, the electrochemical respirometry can give results in less than $48 \mathrm{~h}$ but this method is quite expensive and really labour-intensive.

\subsection{Detection of bacterial inhibitors}

The efficiency of pollution removal by biological treatment processes does not result only from the wastewater $\mathrm{OM}$ characteristics and the fine-tuning of the bioprocess. Indeed, some organic or inorganic compounds occurring in wastewater are able to inhibit the metabolism of the exploited bacteria or to lead to the cell lysis of these micro-organisms. Most of the time, the potential inhibitors do not occur at sufficient concentrations in municipal wastewater to generate such inhibition or cell lysis. However, in industrial wastewater and in municipal wastewater from highly industrial area, the concentrations found could be significant enough [22-23]. In order to prevent STP dysfunction in case of accidental releases of industrial effluents in municipal sewer network, or previously to authorise such release in routine, it should be relevant to assess the impact of these industrial effluents on the metabolism of the exploited bacteria. By this way, it would be possible to determine an acceptable flow rate of potential risky industrial effluents inside the municipal sewer network.

Very few methods can be easily used in the field by STP operators. The ISO 11348 or the NF T 90-320 standards described an analytical method based on the inhibition of the bioluminescence from Vibrio $s p$. Bacteria [23]. However, the relevancy of such bacterial strains which come from marine environment could be subjected to great doubts when using it in the wastewater field. The inhibition effect of wastewater components could also be appraised through the electrochemical 
respiratory, according to the 209 OCDE guideline, using a relevant bacterial consortia collected on a real STP [22-23]. However, as previously mentioned, this technique is too expensive and labour-intensive to be used in routine.

Consequently, the inexpediency of the current analytical methods with the operational constraints makes that the inhibitory effect of industrial effluents are rarely assessed by STP operators despite an obvious interest for this kind of analysis.

\section{Fluorimetric respirometry}

\subsection{Origin of the method}

In the first decade of the present century, a collaborative work carried out by French research institutes and universities led to a particularly innovative method to assess the biodegradability of OM by soil bacteria [24]. They used a fluorescent resazurin-based indicator, which is highly sensitive to the respiration of living organisms, in order to quantify the extent of the OM mineralization (Fig. 2). Even though this indicator was previously used for biomedical and agri-food applications [25-26], it was never use for testing the biodegradability of OM by environmental bacteria. Consequently, this invention was patented [27].

In 2010, a start-up company was founded with the goal to turn this original idea into a reliable and commercial analytical solution for BOD measurement in water sample. This development was led in collaboration with the Public Sewerage Service of the Greater Paris (SIAAP) within the framework of the Mocopee research program (www.mocopee.fr). As a result of this applied research, new patent applications was submitted in 2011 and 2015 [28-29]. Today, this product, which is sold as an analytical kit to be used in combination with a 96wells fluorescence microplate reader, is delivered under the trademark Enverdi ${ }^{\circledR}$ by the AMS alliance group (www.amsalliance.com) in Europe, Asia and North America.

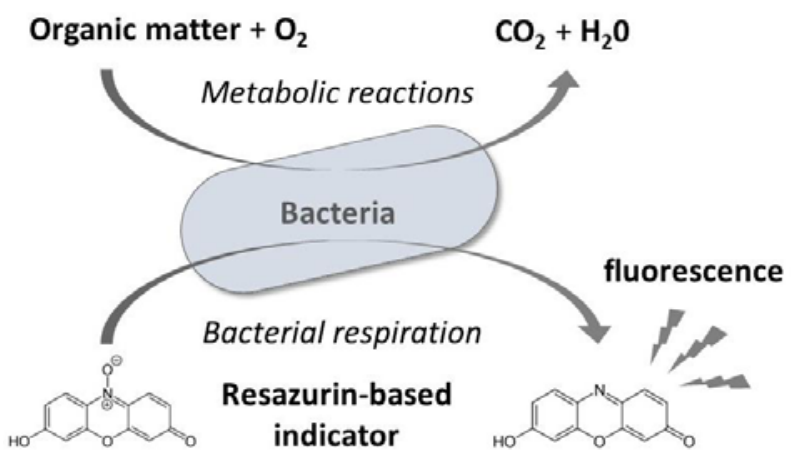

Fig. 2. Simplified principle of the fluorimetric respirometry

\subsection{Analytical principle and design}

The analytical principle is based on the natural mineralization of $\mathrm{BOM}$ by heterotrophic aerobe bacteria (Fig. 2). When $\mathrm{OM}$ is mineralized by such bacteria, the oxygen needed at the final respiration step could be partially replaced by the resazurin-based indicator. Actually, this indicator acts as a final electron acceptor, instead of the oxygen in the bacterial electron transport chain [26, 30-31]. When the indicator is reduced by bacteria, the original molecule is converted into a highly fluorescent product. Given that the indicator reduction is proportional to the bacterial oxygen uptake, the bacterial respiration activity can be quantify through fluorescence intensity measurement [32-34]. This analytical approache can be used to assess the positive or negative effect of a particular substance or an unknown mixture on the bacterial respiration. Exploiting the positive effects we can measure a BOD5-equivalent and achieve $\mathrm{OM}$ fractionation analysis while the detection of bacterial inhibitors relies on the negative effects. Calibration standards of known BOD5 values and blank controls are analysed together with the samples in order to convert the fluorescence intensity into exploitable results (e.g. BOD5-equivalent and $\mathrm{OM}$ fractions in $\mathrm{mg}$ of $\mathrm{O}_{2} . \mathrm{L}^{-1}$ or EC50 inhibition index in $\mathrm{mg}$ of inhibitors. $\mathrm{L}^{-1}$ ). The BOD5 of the calibration standards is determined using the EN 1899-1 standard method.

Thanks to this innovative detection method, the developed analytical solution was easily miniaturised inside a 96-wells microplate which is a standard in numerous analytical field (molecular biology, medical diagnostic, microbiology). Actually, each well of the microplate acts as a mini-bioreactor. Due to the miniaturisation, it was highly conceivable to increase the incubation temperature from 20 to $30^{\circ} \mathrm{C}$ to faster the bacterial mineralization of OM (as explained previously in 1.1.2). Moreover, given that the bacterial respiration is not measured through DO or pressure measurements in the surrounding environment, it was not necessary to hermetically close the wells of the microplate. Consequently, there is absolutely no limitation of the bacterial metabolism by the DO availability since atmospheric oxygen continuously feeds the wells. In these conditions, up-to 96 samples can be analysed simultaneously and results, such like BOD5-equivalent, OM fractions or EC50 index, can be obtained faster than with the usual standard methods. In addition, incubation and agitation of the microplate can be achieved directly in the fluorescence microplate reader. By this way, bacterial respiration can be continuously measured during the time of the test, providing the highest possible responsiveness for operational application in STP.

\subsection{Analytical protocol}

The commercial Enverdi ${ }^{\circledR}$ kit is available for the BOD measurement of municipal wastewater samples (inflow and outflow of municipal STP). This kit contains the resazurin-based reagent, the buffer solution, the calibration standards and some consumables required for the test (96-wells microplates, microplate films, syringes and filters). The $\mathrm{pH}$ and salt buffer solution supplied in the kit is quite similar to the one described in the EN 1899-1 standard. When required, the samples are diluted in a 50-fold diluted buffer (according to the sample 
COD) and the $\mathrm{pH}$ is adjusted between 6 and 8 . Then, the sample are pre-treated to inhibit the activity of indigenous bacteria by heating them at $120^{\circ} \mathrm{C}$ for $10 \mathrm{~min}$ followed by cooling them at $4^{\circ} \mathrm{C}$ for $10 \mathrm{~min}$. By this way, all the samples, calibration standards and quality controls are inoculated in a similar manner. During this time, the bacterial inoculum is prepared by filtering a freshly collected raw wastewater at $1.2 \mu \mathrm{m}$. Afterwards, the wells of the microplate are filled with $20 \mu \mathrm{L}$ of the resazurin-based reagent, $60 \mu \mathrm{L}$ of the buffer solution, $170 \mu \mathrm{l}$ of a calibration standard or a pre-treated sample or a quality control, and $20 \mu \mathrm{L}$ of the raw wastewater filtrate as inoculum. The microplate is immediately sealed with a gas permeable film which permits the oxygen transfer but limits the water evaporation. The fluorescent intensity is recorded every $30 \mathrm{~min}$ for $48 \mathrm{~h}$ when the incubation and agitation of the microplate are carried out inside the microplate reader or every $24 \mathrm{~h}$ for $48 \mathrm{~h}$ when external incubation in preferred (e.g. multiplate analysis using one microplate reader). Calibration and sample quantification are processed automatically through a dedicated computing program. As suggested by the EN 1899-1 and the 5210-B standards, a glucoseglutamic acid mixture can be used as a routine quality control when measuring BOD5-equivalent.

Analytical kits for $\mathrm{OM}$ fractionation analysis or bacterial inhibitor detection are not commercialized yet. These analytical applications are under development in collaboration with the SIAAP. The analytical protocol for $\mathrm{OM}$ fractionation is quite similar except that the calibration standards was completed with a very slowly biodegradable hemi-cellulosic compound in addition to the readily and slowly carbohydrates and proteins used for BOD5 calibration. As a consequence, the incubation period is extended by $24 \mathrm{~h}$ to reach $72 \mathrm{~h}$ in total. Bacterial inhibitor detection is achieved under both inoculum and organic substrate overloaded conditions. The occurrence of inhibitors in wastewater in appraised by spiking different quantity of the wastewater sample in the organic substrate-bacteria mixture. Usually, an incubation period lower than $24 \mathrm{~h}$ is sufficient to observe inhibition or biocide effects. The final fluorescence intensity is compared to a non-inhibiting control and an EC50 inhibition index can be determined by building the dose-response curve.

\section{Method validation for BOD analysis}

\subsection{Initial validation with pilot end-users}

In 2014, a first work was published regarding the BOD result equivalence between the Enverdi ${ }^{\circledR}$ kit and the main BOD5 standard methods (EN 1899-1 and 5210-B) [35]. Around a hundred of municipal wastewater samples were collected and analysed by the SIAAP (Greater Paris, France) and the MMSD (Milwaukee Metropolitan Sewerage District, USA). The results obtained from the Enverdi ${ }^{\circledR}$ and standard methods were compared using different statistical tests according to the international ISO/TS 16489 standard. All these statistical tests showed no significant differences between BOD results obtained from the fluorimetric respirometry and DBO5 values obtained from the European and American standard methods. This conclusion was confirmed later through another comparison study which was published in 2015 [36]. Considering 261 municipal wastewater samples collected and analysed by 4 laboratories ( 3 in France and 1 in USA), no significant differences were found again. The results obtained from 393 municipal wastewater samples collected and analysed from 2013 to 2016 by 6 laboratories ( 5 in France and 1 in USA) are shown in Fig. 3. Using the same statistical tests than in the previously published papers, we showed that the yintercept of the regression curve $\left(\mathrm{r}^{2}>0.94\right)$ was not significantly different from 0 with a $95 \%$ confidence interval $(95 \% \mathrm{CI})$ of $[-3 ; 5]$ and that the slope was not significantly different from 1 with a $95 \%$ CI of $[0.98$; 1.02]. These results proved the absence of, respectively, systematic and proportional bias between the results obtained from both analytical approaches. Based on the Bland and Altman test, similar conclusions can be made. The correlation curve between the normalized error and the average BOD5 of the samples $\left(\mathrm{r}^{2}=0.01\right.$, not illustrated) displayed a slope which was not significantly different from 0 with a $95 \%$ CI of $[-0.0002 ; 0.0424]$. Besides, the median normalized error of the Enverdi ${ }^{\circledR}$ BOD against the standard BOD5 values was equal to 0 and the average normalized error was not significantly different from 0 with a $95 \%$ CI of $[-5 ; 0.3]$. Consequently, when using the Enverdi ${ }^{\circledR}$ kit, no significant over- or underestimation of the BOD5 result was detected. With a $p$ value of $0.8(\alpha=0.05)$, the Wilcoxon test reinforced the fact that the differences between the results from both methods are really negligible.

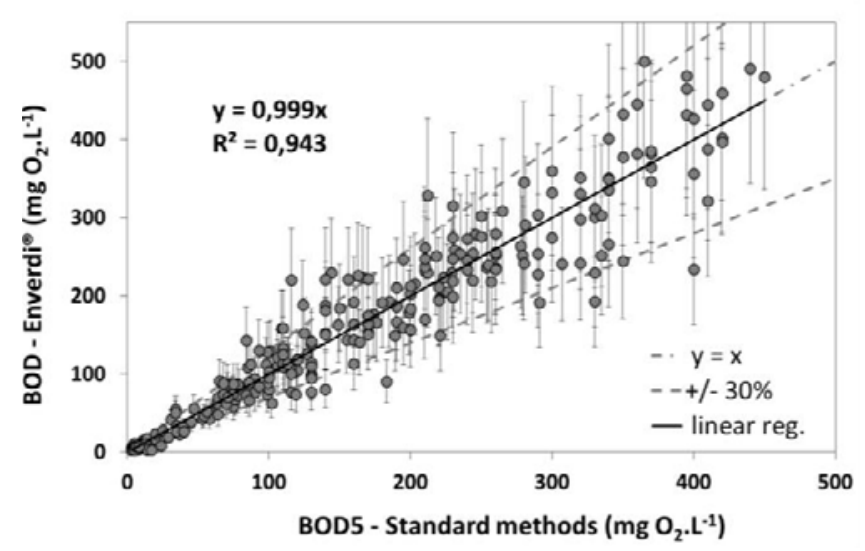

Fig. 3. Correlation between the Enverdi ${ }^{\circledR}$ DBO results and the standard DBO5 values obtained from the analysis of 393 municipal wastewater samples. The " $+/-30 \%$ " dashed lines illustrate the expanded uncertainty range of the standard BOD5 methods.

The statistical comparison of the BOD results obtained by the Enverdi ${ }^{\circledR}$ and the standards method on quite 400 samples of municipal wastewater clearly showed a strong equivalence. For about $98 \%$ of the analysed samples, the Enverdi ${ }^{\circledR}$ DBO result felt in the uncertainty range of the standard methods. This conclusion is consistent with the previous studies carried 
out with lower sample populations $[35,36]$. In addition, this equivalence demonstration is based on analysis performed over long time periods (from several months to 1 year), in different locations in France and USA, with sample BOD5 values ranging from 3 to $500 \mathrm{mg} \mathrm{O} \cdot \mathrm{L}^{-1}$. As a consequence, this comparison takes in account the potential geographical and temporal variability of the wastewater characteristics, including the metabolic properties of the bacterial consortia used as inoculum, as well as the diversity of practices and skills occurring in laboratories. Otherwise, the strong equivalence between the Enverdi ${ }^{\circledR}$ BOD, obtained after a " $2 \mathrm{~d} / 30^{\circ} \mathrm{C}$ " incubation period, and the standard BOD5, obtained after a " $5 \mathrm{~d} / 20^{\circ} \mathrm{C}$ " incubation period, is in accordance with the time-temperature binomials studies carried out by other researchers using the standard method (Fig. 1). This strong equivalence also confirms concomitant works showing that the fluorescence intensity resulting from the reduction by bacteria of a resazurin-based reagent is clearly correlated to the bacterial oxygen uptake for BOM mineralisation [32-34].

Additionally to the equivalence studies between the Enverdi ${ }^{\circledR}$ BOD results and the BOD5 values obtained from standard methods, the analytical specifications of the Enverdi ${ }^{\circledR}$ BOD kit were assessed. This work was carried out by two different laboratories in France according to the validation standards in force in the water quality field (NF T90-210 and ISO 11352). The analytical specifications are summarized in Table 1. Such results match the European and French regulation requirements and are comparable to the analytical specifications of the EN 1899-1 standard method. Regarding the calibration range, wastewater samples can be analysed without dilution by the Enverdi ${ }^{\circledR}$ method up to BOD5 values of $90 \mathrm{mgO}_{2} \cdot \mathrm{L}^{-1}$. Comparatively, considering the DO limitation of the standard method, the recommended dilution factor for a BOD5 value of 90 $\mathrm{mgO}_{2} \cdot \mathrm{L}^{-1}$ is around 20. The absence of DO limitation in the Enverdi ${ }^{\circledR}$ method leads to a larger linear calibration range and 20-fold lower sample dilutions. Consequently, the calibration range of the Enverdi ${ }^{\circledR}$ method could greatly reduce the risk of dilution errors.

Table 1. Analytical specifications of the Enverdi ${ }^{\circledR}$ BOD kit.

\begin{tabular}{|c|c|}
\hline Specification tested & Result \\
\hline $\begin{array}{c}\text { Limit of quantification } \\
N F T 90-210\end{array}$ & $3 \mathrm{mg} \mathrm{O} \cdot \mathrm{L}^{-1}$ \\
\hline Calibration range & linear up to : \\
$N F$ T90-210 & $90 \mathrm{mg} \mathrm{O} \cdot \mathrm{L}^{-1}$ \\
\hline Accuracy & satisfactory at : \\
$N F$ T90-210 & $3,9,15,37,50,160 \mathrm{mg} \mathrm{O}_{2} . \mathrm{L}^{-1}$ \\
\hline Expanded uncertainty & from 3 to $6 \mathrm{mg} \mathrm{O}_{2} \cdot \mathrm{L}^{-1}:$ \\
ISO 11352 & above $6 \mathrm{mg} \mathrm{O}_{2} \cdot \mathrm{L}^{-1}:$ \\
& $\pm 30 \%$ \\
\hline
\end{tabular}

To complete the validation of the fluorimetric respirometry for BOD5 measurement, four analysis were realized within the framework of inter-laboratory comparisons (ILC) run by two French accredited bodies (A and B). Three of these ILC were based on real municipal wastewater samples with BOD5 values at 6 , 67 and $168 \mathrm{mgO}_{2} \cdot \mathrm{L}^{-1}$ (Fig. 4). In these conditions, highly satisfactory $\mathrm{z}$-score $(< \pm 1)$ were obtained for both the Enverdi ${ }^{\circledR}$ kit and the standard method. For unidentified reasons, the last ILC, based on a spiked municipal wastewater at $40 \mathrm{mgO}_{2} \cdot \mathrm{L}^{-1}$, led to unsatisfactory z-score for the Enverdi ${ }^{\circledR}$ kit while the standard method matched the laboratory average value (not illustrated). Nevertheless, further internal studies, involving different bacterial inocula, collected in different locations in France and during different seasons, have ascertained the efficiency of the Enverdi ${ }^{\circledR}$ BOD kit to accurately quantify such spiked municipal wastewater samples at 25 and $50 \mathrm{mgO}_{2} \cdot \mathrm{L}^{-1}$ (not illustrated).

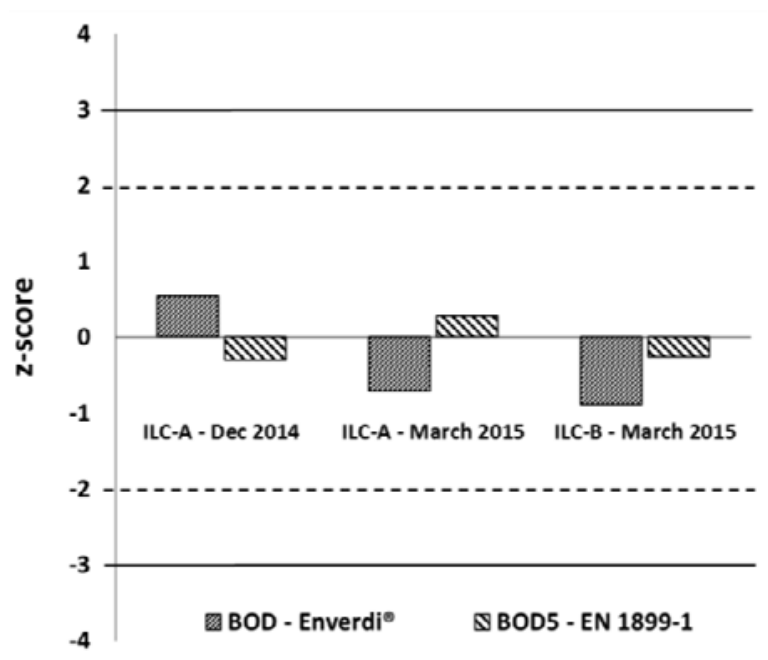

Fig. 4. Results of inter-laboratory comparisons including both Enverdi ${ }^{\circledR}$ BOD and EN 1899-1 standard analysis of real municipal wastewater samples. Satisfactory results were obtained when the z-score range from -2 to 2 .

The initial validation of the Enverdi ${ }^{\circledR}$ method for BOD5 measurement which involved pilot end-users was really successful. Result equivalence with the standard methods and high analytical performances on municipal wastewater was clearly shown.

\section{2 final validation for regulatory acceptance}

Despite the good results obtained during the 4 years initial validation, the routine use of the Enverdi ${ }^{\circledR}$ kit by laboratories for BOD5 measurement was stopped by the French and European regulatory framework. Indeed, only the EN 1899-1 standard is allowed in France and any procedure exists for the regulatory acceptance of innovative methods in the field of water analysis. In order to address such shortcomings, the French authorities started a new program in 2016 called "France Experimentation". Thanks to this program, based on an article of the French constitution, temporary decrees can be adopted by derogation to experiment innovative methods, processes or services and assess the effect of future regulation changes. Thus, such a decree will be 
published in 2017 for the national experimentation of the BOD monitoring in municipal STP through the fluorimetric respirometry. In agreement with the European regulations, the experiment will last for 2 years and will concern the municipal STP located in four of the six hydrographic districts of the mainland France. The laboratories taking part in this experiment must be accredited on the standard BOD5 method. After preliminary characterisation and validation assays (analytical specifications, result equivalence and ILC), the involved laboratories will be able to substitute the EN 1899-1 standard method with the Enverdi ${ }^{\circledR}$ BOD method for up to $50 \%$ of the BOD5 inspections required by the French regulation in municipal STP. Both methods will be alternated at least monthly (or more frequently if possible) in order to avoid bias due to seasonal variations or changes in STP operation. This experiment will be overseen and appraised by a special national committee. If the results are satisfactory, the experimental regulation could be fully and durably included in the French regulations. Consequently, the innovative method could be use in routine by laboratories for BOD5 measurement in municipal STP.

\subsection{Limitations and further improvements}

Regarding the biological interference due to nitrifying bacteria using the Enverdi ${ }^{\circledR}$ method, comparative analysis were performed with and without allylthiourea (ATU). No significant differences were found between results obtained from both protocols over a variety of real STP samples (inflow and outflow) and standard solutions (not illustrated). This means that the nitrifying bacteria show insignificant activity before $48 \mathrm{~h}$ when incubated at $30^{\circ} \mathrm{C}$. This conclusion is consistent with previous published results indicating that, even though $30^{\circ} \mathrm{C}$ is an optimal temperature for nitrifying bacteria, nitrification does not start before the seventh day in DBO tests carried out at such temperature [13].

Besides, no significant chemical interferences with the resazurin-based reagent were found for a large panel of chemicals at expected concentrations in municipal wastewater or STP effluents (not illustrated). This panel included metals, salts, nutrients and organic surfactants. However, in industrial wastewater, some of these chemicals could occur in sufficient concentration to induce bias in BOD measurement. For such samples, preliminary studies should be carefully realized previous to use the Enverdi ${ }^{\circledR}$ kit in routine. Nevertheless, consistent results were obtained when measuring BOD5aquivalent of industrial wastewaters in fluorimetric respirometry, particularly with paper mill effluents, agrifood effluents and landfill leachates. The Enverdi ${ }^{\circledR}$ BOD kit was used with success for the BOD5 measurement of pig slurry samples also [37].

Samples with high content of particulate matter, like pig slurries, must be homogenised before analysis by dispersing the particulate fraction (as recommended by the EN 1899-1 standard). However, such a pre-treatment is useless for municipal wastewater samples. Indeed, given the microvolumes used with the Enverdi ${ }^{\circledR}$ method, the representativeness of the test sample is of particular concern. However, the results of Enverdi ${ }^{\circledR}$ BOD analysis on different granulometric fractions $(<0.1 \mu \mathrm{m}$, $<1 \mu \mathrm{m}$ and total) of a municipal wastewater from the Greater Paris (collected at three different dates: I, II and III) perfectly matched the BOD5 results obtained with the standard method on the same fractions (Fig. 5). These results proved that the Enverdi ${ }^{\circledR}$ kit is rigorously sensitive to the particulate BOM which is mineralized during the BOD5 analysis and that the test sample microvolume is representative enough.

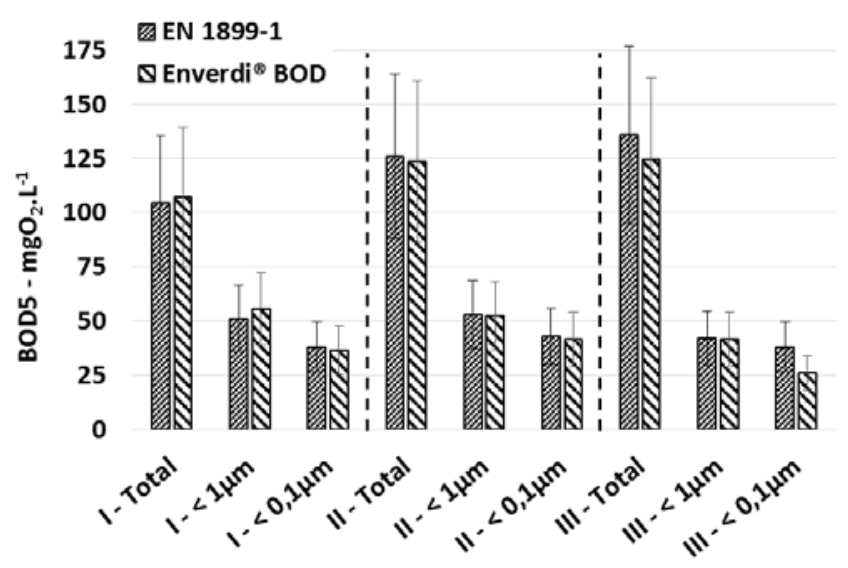

Fig. 5. Results of Enverdi ${ }^{\circledR}$ BOD and EN 1899-1 standard analysis on different granulometric fractions $(<0.1 \mu \mathrm{m},<1 \mu \mathrm{m}$ and total) of the same municipal wastewater sample collected at three different dates (I, II and III). Error bars = expanded uncertainty $( \pm 30 \%)$.

Up to now, the Enverdi ${ }^{\circledR}$ method is not sensitive enough for BOD measurement in freshwater. For that purpose, the limit of quantification (LOQ) should be 0.5 $\mathrm{mgO}_{2} \cdot \mathrm{L}^{-1}$ while the current LOQ is $3 \mathrm{mgO}_{2} \cdot \mathrm{L}^{-1}$. However, a more sensitive version of the Enverdi ${ }^{\circledR}$ BOD kit, especially designed for freshwater analysis, is under development. A first porotype will be available for pilot tests at the end of 2017.

Two other improvements are currently investigated. The first issue is about the automatization of the analytical protocol including both sample dilutions and microplate preparation. In addition to be time-saving, such a technical outlook could greatly contribute to reduce the dilution and operator errors resulting in more accurate results. The second issue deals with the development of a standard bacterial consortium for sample inoculation. Indeed, the commercial freeze-dried inocula currently available for BOD5 measurement (e.g. PolySeed $\AA$ supplied by InterLab $\AA$ is the most common in France) are not efficient enough to be used with the Enverdi ${ }^{\circledR}$ kit. Even though such products perfectly work under the standard conditions, the bacteria found in these products are probably not adapted to the Enverdi ${ }^{\circledR}$ conditions (i.e. short incubation period at $30^{\circ} \mathrm{C}$ ). Moreover, preliminary acclimation periods did not improve their capacities. Consequently, a standard inoculum solution, especially designed for the Enverdi ${ }^{\circledR}$ BOD kit, was developed and will be available for pilot tests at the end of 2017. This standard inoculum could be used with the standard BOD5 methods as well. 


\section{Applications for bioprocess operation}

\subsection{Organic matter fractionation}

Besides the BOD5-equivalent measurement, the fluorimetric respirometry could be used for wastewater OM fractionation according the ASM1 fractionation model (see 1.2). In 2016, within the framework of the Mocopee research program, three different analytical methods were compared for that purpose. Analysis were carried out on a wastewater from the Greater Paris collected at three different dates (February, March and April). The analytical methods used were the manometric respirometry (i.e. manometric BOD), the electrochemical respirometry (i.e. OUR test) and the fluorimetric respirometry (Enverdi $\left.{ }^{\circledR}\right)$. Both manometric and electrochemical respirometric methods were performed at $20^{\circ} \mathrm{C}$ for, respectively, 15 and 2 days. The fluorimetric respirometry was performed at $30^{\circ} \mathrm{C}$ for 3 days. No wastewater filtration was required in electrochemical respirometry while filtrations at 0.1 and $1 \mu \mathrm{m}$ were applied for $S s$ determination using the manometric and fluorimetric methods. Oxygen demand of each fractions was expressed as a percentage of the $t C O D$. The OM fractionation profiles obtained by each of these methods are illustrated in Fig. 6.
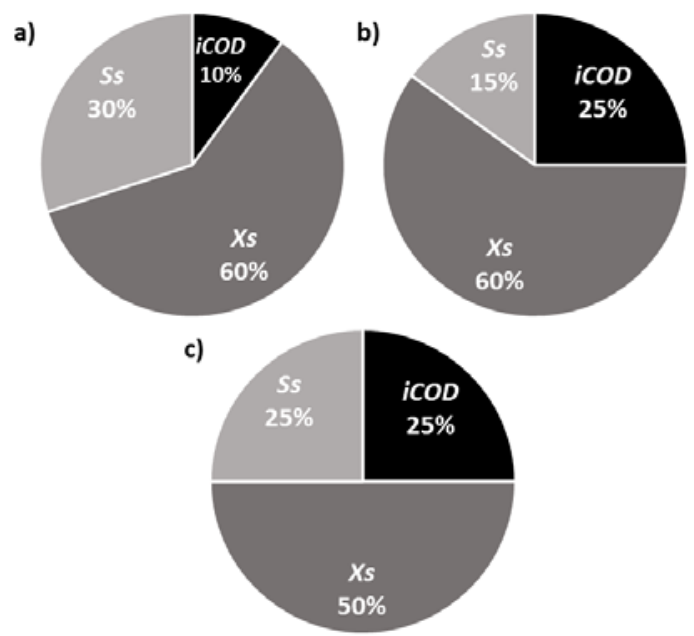

Fig. 6. Results of wastewater OM fractionation analysis using the manometric respirometry (a), the electrochemical respirometry (b) and the fluorimetric respirometry (c). The oxygen demand of each fractions is expressed as a percentage of the $t C O D$. Each OM fractionation profile results from three experiments carried out with the same wastewater collected at three different dates.

The results showed that the OM fractionation profile obtained with the Enverdi ${ }^{\circledR}$ method is consistent with the ones obtained by the reference methods. Both electrochemical and fluorimetric methods led to $b C O D$ and $i C O D$ fraction counting for, respectively $75 \%$ and $25 \%$ of the $t C O D$. Comparatively, $b C O D$ counted for $90 \%$ using the manometric respirometry while $i C O D$ counted for only $10 \%$. The $S s$ and $X s$ fractions found with Enverdi ${ }^{\circledR}$ are quite similar to the ones obtained by the manometric respirometry (respectively, 25 and 50\% versus $30 \%$ and $60 \%$ ). Inversely, the $S s$ fraction counted for only $15 \%$ with the electrochemical respirometry. To sum-up, both electrochemical and fluorimetric approaches tend to underestimate the $b C O D$ fraction but, unlike the electrochemical respirometry, the bias with Enverdi ${ }^{\circledR}$ is constant over the different campaigns and could be supressed using a correction factor. Nevertheless, the $S S / X S$ ratio found with Enverdi ${ }^{\circledR}$ is similar to the one found with the manometric method (around 1:2). This ratio is significantly different when using the electrochemical respirometry (around 1:4). Thus, even though improvements should be made to match better the fractionation profile obtained from the manometric method, the results obtained by Enverdi ${ }^{\circledR}$ are in the same order of magnitude than the ones obtained by the main reference methods. In addition, the Enverdi ${ }^{\circledR}$ protocol is much faster than the manometric respirometry and largely less tedious, expensive and time consuming than the electrochemical respirometry. Thus, the wastewater OM fractionation through the Enverdi ${ }^{\circledR}$ method constitutes an interesting compromise between result accuracy and operational suitability.

\subsection{Detection of bacterial inhibitors}

The use of resazurin-based reagents for the detection of biocide or metabolic inhibition effects is not really a new issue. This application is common in the bio-medical field [38-40] and progressively arises in environmental research [41-43]. Even in wastewater treatment some investigations were made [34] but knowledge about it is still poor. Consequently, in collaboration with the SIAAP, the application of the Enverdi ${ }^{\circledR}$ method for the detection and assessment of inhibitory effects in wastewater was studied. First of all, the Enverdi ${ }^{\circledR}$ method was compared to the electrochemical respirometry as a reference method using standard solutions of inhibitors at different concentrations. As an example, the EC50 index of copper ion and 3,5dichlorophenol $(3,5 \mathrm{DCP})$ on activated sludge activity is shown in Fig. 7. For each compounds, three analysis were performed at different dates using for both methods a fresh sample of activated sludge collected from a STP in the Greater Paris.

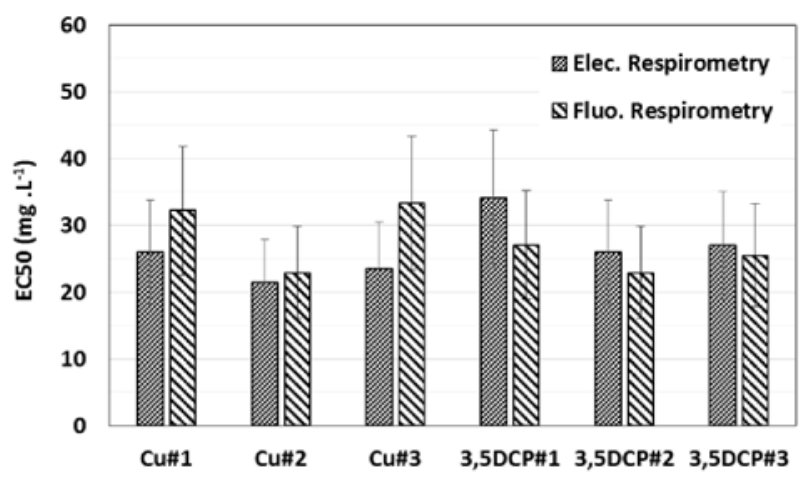

Fig. 7. EC50 index of copper ion $(\mathrm{Cu})$ and 3,5-dichlorophenol $(3,5 \mathrm{DCP})$ on activated sludge activity obtained by the electrochemical respirometer (Elec. Respirometry) and the Enverdi ${ }^{\circledR}$ method (Fluo. Respirometry). Error bars = expanded uncertainty $( \pm 30 \%)$ 
These results showed that the EC50 index obtained by the two methods are quite similar, ranging from 20 to $35 \mathrm{mg} . \mathrm{L}^{-1}$ for both inhibitors. Further experiments are planned for 2018 in order to complete this comparison with real industrial wastewater samples. Moreover, the extrapolation of the test result to a real biological treatment process will be investigated more accurately. Nevertheless, the fluorimetric respirometry could be a relevant alternative to the electrochemical respirometry for the detection and assessment of biocide inhibitory effects in wastewater. In addition, this method is much less tedious and costly than the reference method.

\section{Conclusions}

Given the operational challenges for STP operators due to high quality freshwater, energy saving and global warming control demands at once, the optimization of biological treatment processes according to wastewater characteristics is a major issue. For such optimization, STP operators need fast and easy-to-use analytical methods as well as finely tuned mathematical models. Particularly, the BOD measurement, the OM fractionation and the bacterial inhibition effect detection are essential. In this paper, we shown that the fluorimetric respirometry, commercialized as a patented analytical kit under the trademark Enverdi ${ }^{\circledR}$, constitutes a very interesting solution to satisfy these needs. The result equivalence of the Enverdi ${ }^{\circledR}$ BOD kit in comparison with the main standard BOD5 methods have been clearly demonstrated on municipal wastewater and effluents. This alternative method has shown satisfactory analytical performances on such samples as well. Further improvements will enable soon the analysis of freshwater samples, the use of a standard bacterial consortium as inoculum and the complete automatization of the analytical protocol. Besides the scientific and technical aspects, the next step is the regulatory acceptance in France, in accordance with the European directives, which is essential to hope for a routine use in laboratories. For this goal, we feel very confident about the success that will be met by the imminent 2 -years experiment under the French authorities' supervision.

In addition to the BOD5 measurement application, this technology has shown promising abilities for wastewater OM fractionation according to the ASM1 fractionation model as well as for detection and assessment of bacterial inhibitory effects in municipal STP inflow and in industrial wastewater. Such supplementary applications could be very useful to reach an optimal operation of biological treatment processes in municipal STP.

The major advantages of the fluorimetric respirometry in comparison to the standard methods currently used for each applications investigated is mainly the time- and space-saving, the low investment required as well as the user-friendliness.

The authors are grateful to Laure Menjou, Jean-Francois Moisan, Audrey Janot, Perrine Meche, Amandine Bavouzet, Jean Bernier and Jialu Zhu from the SIAAP for their great technical and scientific contribution to this work. We are thankful to Yves Dudal, Romy-Alice Goy, Nathalie Pautremat, Audrey Magnin, Margot Rodriguez and Vincent Ferrandini which were valuable and vital collaborators to succeed. We also thank André Pauss from the Technical University of Compiegne (UTC) for its scientific advice. Finally, we acknowledge the research program "MOCOPEE" (MOdeling, Control and Optimization of wastewater treatment ProcEssEs) for its financial support as well as the French National Institute for Agricultural Research (INRA) for the benefit from the exclusive licence patent agreement.

\section{References}

1. M. Henz. Biological Wastewater Treatment: Principles Modelling and Design (IWA Publishing, London, 2008).

2. Council Directive 91/271/EEC. Urban wastewater treatment (JO L 135, p. 40-52, 1991)

3. S. Jouanneau, L. Recoules, M.J. Durand, A. Boukabache, V. Picot, Y. Primault, A. Lakel, M. Sengelin, B. Barillon, G. Thouand. Water Research, 49, p. 62-82 (2014).

4. J. Liu, B. Mattiasson. Water Research, 36, p. 37863802 (2002).

5. S. Azimi, V. Rocher. Water Practice and Technology, 12, p. 104-116 (2017).

6. R. D. Tyagi, D. Couillard. The Canadian Journal of Chemical Engineering, 66, p. 97-106 (1988).

7. R.M. Harrison. Pollution: Causes, Effects and Control (Royal Society of Chemistry, Cambridge, 2001).

8. D. Mara, N.J. Horan. Handbook of Water and Wastewater Microbiology (Academic Press/Elsevier, London, 2003).

9. Royal Commission on Sewage Disposal. Treating and disposing of sewage. Final report (Her Majesty's Stationery Office, London, 1915).

10. H.T. Calvert. Journal of the Society of Chemical Industry, 32, p. 265-274 (1913).

11. M.P. de Matos, A.C. Borges, A.T. de Matos, E.F. da Silva, M.A. Martinez. Engenharia Agrícola, 34, p. 332-340 (2014).

12. A. van Haandel, J. van der Lubbe. Handbook of Biological Wastewater Treatment: Design and Optimisation of Activated Sludge Systems (IWA Publishing, London, 2012).

13. A.E. Zanoni. Water Research, 1, p. 543-566 (1967)

14. S.S. Dhage, A.A. Dalvi, D.V. Prabhu. Environmental Monitoring and Assessment, 184, p. 5301-5310 (2012).

15. E. J. Theriault. US Public Health Reports, 41, p. 207217 (1926).

16. E. J. Theriault. US Public health Bulletin, 173 (1927).

17. H.B. Gotaas. Sewage Works Journal, 20, p. 441-477 (1948).

18. French Decree DEVL1429608A. Relatif aux systèmes d'assainissement (JORF 0190, p. 14457, 2015).

19. S. Cavalieri, V. Giacomelli, M. Mazzoni. I macrodescrittori del decreto legislativo 152/99. 
Rassegnat Dei Metodi Analitici e di camionamento (Agenzia Nazionale per la Protezione dell'Ambiente, Roma, 2000).

20. M. Henze, W. Gujer, T Mino, M. van Loosdrecht. Activated Sludge models ASM1, ASM2, ASM2d and ASM3 (IWA Publishing, London, 2000).

21.S. Gillot, J.M. Choubert. Water Science and Technology, 62, p. 630-639 (2010).

22. V. Surerus, G. Giordano, L.A.C. Teixeira. Brazilian Journal of Chemical Engineering, 31, p. 385-392 (2014).

23. P. Foladori, L. Bruni, S. Tamburinic. Journal of Hazardous Materials, 280, p. 758-766 (2014).

24. Y. Dudal, R. Holgado, K. Knoth, M. Debroux. Analytical and Bioanalytical Chemistry, 384, p. 175179 (2006).

25. J. O'Brien, I. Wilson, T. Orton, F. Pognan. European Journal of Biochemistry, 267, p. 5421-5426 (2000).

26. S.N. Rampersad. Sensors, 12, p. 12347-12360 (2012).

27. Y. Dudal, E. Guillon, L. Dupont, H. Quiquanpoix, J.L. Boudenne. European Patent 1844330 (2007).

28. N. Pautremat, R.A. Goy, Z. El Amraoui, Y. Dudal. European Patent 2597461 (2013).

29. M. Muller, R.A. Goy, A. Yoris, A. Magnin, Y. Dudal. International Patent 2016184848 (2016).

30. E.M. Larson, D.J. Doughman, D.S. Gregerson, W.F. Obritsch Investigative Ophthalmology \& Visual Science, 38, p 1929-1933 (1997).

31. D. Karakashev, D. Galabova, I Simeonov. World Journal of Microbiology \& Biotechnology, 19, p 233-238 (2003).

32. R. González-Pinzón, R. Haggerty, D.D. Myrold. Journal of Geophysical Research, 117, p 1-10 (2012).

33. R. González-Pinzón, M. Peipoch, R. Haggerty, E. Martí, J.H. Fleckenstein. Ecohydrology, 9, p 93-100 (2015).

34. B.P. McNicholl, J.W. McGrath, J.P. Quinn. Water Research, 41, p 127-133 (2007).

35. M. Muller, S. Bouguelia, R.A. Goy, A. Yoris, J. Berlin, P. Meche, R. Rocher, S. Mertens, Y. Dudal Environmental Science and Pollution Research. 21, p. 13642-13645 (2014).

36. A. Magnin, M. Muller, A. Yoris, S. Guérin, V. Rocher, Y. Dudal. 17 $7^{\text {th }}$ International Congress of Metrology (EDP Sciences, Les Ulis, 2015).

37. J. Nehmtow, J. Rabier, R. Giguel, B. Coulomb, A.M. Farnet, C. Perissol, A. Alary, I. Laffont-Schwob. Environmental Science and Pollution Research, 23, p 16383-16395 (2016).

38. N. Lall, C.J. Henley-Smith, M.N. De Canha, C.B. Oosthuizen, D. Berrington. International Journal of Microbiology, doi:10.1155/2013/420601 (2013).

39. A. Gahlaut, A.K. Chhillar. International Journal of Pharmacy and Pharmaceutical Sciences, 5, p. 372376 (2013).

40. M.J. Natto, F. Savioli, N.B. Quashie, C. Dardonville, B. Rodenko, H.P. de Koning. Journal of Antimicrobial Chemotherapy, 67, pp. 933-943 (2012).

41.P.B. Fai, A. Grant. Chemosphere, 74, p. 1165-1170 (2009).
42. P.B. Fai, A. Grant. Chemosphere, 75, p. 289-296 (2009).

43. R.N. Montagnolli, P.R.M Lopes, E.D. Bidoia. Archives of Environmental Contamination and Toxicology, 68, p. 342-353 (2015). 